\title{
Sterilisasi Komersial Cassava Chunk pada Kemasan Hermetis Standing Pouch dan Perubahan Sifat Fisikokimianya
}

\section{(Commercial Sterilization of Cassava Chunk in Hermetic Standing Pouch Packages and the Changes in Physicochemical Properties)}

\author{
Dewi Sartika Saragih*, Dede Robiatul Adawiyah, Fransisca Zakaria Rungkat
}

(Diterima Mei 2020/Disetujui Januari 2021)

\begin{abstract}
ABSTRAK
Perubahan gaya hidup masyarakat cenderung menginginkan makanan praktis dan sehat yang sangat didukung dengan diet sehat. Singkong sangat berpotensi sebagai pangan sehat untuk substitusi beras, namun perlu teknologi tepat guna untuk mempermudah penyajiannya. Produk singkong siap saji dapat diproduksi dengan menerapkan teknologi pengalengan menggunakan kemasan retort pouch (jenis standing pouch). Tercapainya nilai kecukupan panas $\left(F_{0}\right)$ sangat penting dalam pengalengan untuk menjamin keamanan pangan. Penelitian ini bertujuan untuk menghasilkan produk singkong utuh siap saji (cassava chunk), mengoptimasi ukuran dan jumlah larutan garam pada proses sterilisasi, menentukan nilai $F_{0}$ dengan perlakuan blansir dan tanpa blansir, serta karakterisasi kimia singkong segar dan produk cassava chunk. Sterilisasi dilakukan menggunakan panci presto dengan keranjang yang didesain secara khusus. Karakterisasi awal menunjukkan bahwa singkong segar memiliki pH 6,70 dan aw 0,9 pada suhu $24,6^{\circ} \mathrm{C}$. Penambahan larutan garam $1 \%$ sebanyak $20 \%$ pada proses sterilisasi dengan ukuran chunk $3 \times 2,5 \mathrm{~cm}$ paling disukai para panelis. Proses sterilisasi dengan perlakuan blansir 5 menit sebelum dikemas dan sterilisasi pada suhu $111^{\circ} \mathrm{C}$ selama 45 menit mencapai $F_{0}$ selama 3,43 menit artinya aman dikonsumsi dan yang tidak diblansir sebelum dikemas hanya mencapai Fo selama 2,73 menit. Hasil analisis proksimat cassava chunk menunjukkan peningkatan kadar air dari 60,89 menjadi $68,44 \%$, kadar pati dari $74,43 \%$ menjadi $80,41 \%$, tetapi kadar lemak menurun dari $1,54 \%$ menjadi $0,65 \%$. Sementara itu, kadar abu, protein, dan serat pangan tidak menunjukkan perbedaan secara statistik setelah sterilisasi. Teknologi sterilisasi dapat menghasilkan produk cassava chunk, yaitu singkong utuh siap santap dan diterima oleh 45 panelis dalam uji organoleptik.
\end{abstract}

Kata kunci: analisis proksimat, cassava chunk, nilai $F_{0}$, pangan utuh

\section{ABSTRACT}

People's lifestyles nowdays tend to want healthy-practical food that is strongly supported by a healthy diet. Cassava as whole food is considered as a healthy food and has the potential to become rice substitute but needs an appropriate technology to facilitate food serving. In this research, ready-to-eat cassava products then called "cassava chunk" were made by applying canning technology using retort pouch packaging. The achieved value of the heat adequacy $\left(F_{0}\right)$ is very important in the canning process to ensure food safety. Therefore, this study aimed to produce cassava chunk product as a whole food, optimize the size and amount of brine in the sterilization process, determine the $F_{0}$ value after blanching and non-blanching treatments, as well as to analyze the chemical characteristics of fresh cassava and cassava chunk. The sterilization was done by using a pressure cooker with a specially designed basket using hermetic retort pouch packaging. The initial characterizations showed that fresh cassava had a pH of 6.70 and $0.9 \mathrm{a}_{\mathrm{w}}$ at $24.6^{\circ} \mathrm{C}$. The addition of $20 \%(\mathrm{~b} / \mathrm{v}) 1 \%$ brine solution in the sterilization process with $3 \times 2.5 \mathrm{~cm}$ cassava chunk was the most preferred by the panelists. The sterilization process with blanching treatment before being packaged reached an $F_{0}$ of 3.43 minutes, which was safe to consume, and with non-blanching treatment before being packaged reached an $F_{0}$ of 2.73 minutes. The proximate analysis of cassava chunk showed an increase in the water content from $60.89 \%$ to $68.44 \%$, the starch content increased from $74.43 \%$ to $80.41 \%$, the soluble dietary fiber decreased from $6.78 \%$ to $3.34 \%$, but the fat content decreased from $1.54 \%$ to $0.65 \%$. Meanwhile, ash, protein, and insoluble dietary fiber did not show any significant differences after the sterilization. Sterilization technology could produce ready-toeat cassava chunk as a whole food and was acceptable by $\mathbf{4 5}$ organoleptic panelists.

Keywords: cassava chunk, whole food, proximate analysis, $F_{0}$

Departemen Ilmu dan Teknologi Pangan, Fakultas Teknologi Pertanian, Institut Pertanian Bogor, Kampus IPB Darmaga, Bogor 16680

* Penulis Korespondensi:

Email: dewi_sartikasaragih@apps.ipb.ac.id

\section{PENDAHULUAN}

Seiring dengan perkembangan zaman, manusia ingin mendapatkan makanan yang serba praktis. Perubahan gaya hidup masyarakat cenderung 
mengkonsumsi makanan kurang sehat dan makanan olahan telah diketahui menyebabkan terjadinya penyakit tidak menular (PTM). Untuk mencegah PTM perlu diet sehat (WHO 2020). Contoh diet sehat adalah pangan nabati utuh yang masih mengandung hampir semua komponen pangan yang dapat dimakan yang dimiliki secara alami, yaitu protein, karbohidrat, lemak, vitamin, mineral, serat, dan komponen bioaktif. Pangan utuh yang dimaksud adalah pangan yang tidak mengalami proses ekstraksi, pemisahan, dan atau pemurnian (refine food) yang dapat menghilangkan sejumlah komponen pangan, terutama komponen bioaktif sehingga secara komposisi masih menyerupai bahan segar (Zakaria 2015). Pangan utuh bisa mengalami pengolahan minimal, termasuk perubahan bentuk, seperti pemotongan dan penepungan (Zakaria 2015). Di Indonesia, singkong atau cassava sangat berpotensi sebagai substitusi beras dari segi nilai gizi dan sumber karbohidrat yang cukup banyak setelah beras. Produksi singkong mencapai 21,8 juta ton pada tahun 2015 (BPS 2019).

Singkong mengandung $40 \%$ serat larut yang terdiri atas asam uronat, pektin, dan $\beta$-Glukan (Post et al. 2012), sedangkan fraksi tidak larut kaya akan selulosa dan lignin (Infante et al. 2013). Singkong digolongkan ke dalam makanan yang kaya serat. Serat makanan bergantung pada kandungan karbohidrat makanan dan struktur pati yang bertindak sebagai penentu indeks glikemik rendah (Infante et al. 2013; Eleazu et al. 2015; Eleazu 2016).

Analisis proksimat varietas singkong Adira umur 7 bulan memiliki kadar air 66,20\%, lemak kasar 0,83\%, protein kasar 2,45\%, serat kasar 0,73\%, kadar abu $0,66 \%$, dan karbohidrat 29,17\% (Feliana et al. 2014). Singkong sangat berpotensi sebagai substitusi nasi, namun perlu teknologi tepat guna untuk mempermudah penyajian. Penelitian ini belum pernah dilakukan dan butuh proses panjang untuk menghasilkan produk baru berupa potongan singkong utuh siap santap yang selanjutnya disebut dengan "cassava chunk" steril. Produk ini diharapkan mampu menggantikan nasi dan mudah didapatkan di mana saja. Cassava chunk bersifat praktis yang bisa dikonsumsi langsung atau bisa juga diolah lagi sesuai dengan selera. Cassava chunk, jika diolah dalam skala industri, akan mudah tersedia di mana saja sehingga akan mempermudah masyarakat untuk mengonsumsinya sebagai pengganti nasi. Cassava chunk dapat digunakan sesuai dengan selera dan kemauan konsumen, misalnya untuk mengantikan lontong nasi sebagai pelengkap sate atau gado-gado.

Pengolahan cassava chunk yang ready to eat (RTE) dapat dilakukan dengan menerapkan teknologi pengalengan menggunakan kemasan retortable pouch. Retortable pouch merupakan kemasan berlapis (laminat) yang bersifat fleksibel dan tahan suhu tinggi, yaitu suhu operasional retort. Beberapa keunggulan kemasan ini dibandingkan dengan kemasan kaleng ialah lebih mudah, murah, praktis, mudah dibuka, hemat energi dalam hal distribusi panas, efektif dalam penyimpanan, dan memberikan fleksibilitas dalam desain grafis untuk keperluan pemasaran (Kumar et al. 2013; Virat et al. 2014). Masalah yang dihadapi adalah potongan ubi kayu bisa menjadi bubur, penurunan mutu sensori, serta tercapainya nilai kecukupan panas produk tersebut. Kriteria cassava chunk yang dikehendaki ialah warna masih menyerupai umbi aslinya dan tidak menyerupai bubur (overcook). Kriteria tersebut dapat dicapai dengan optimasi ukuran, pengaturan larutan garam yang digunakan dalam kemasan pouch, dan perlakuan blansir atau tanpa blansir sebelum dikemas untuk melihat nilai $F_{0}$. Suhu dan lama pemanasan juga akan memengaruhi tingkat gelatinisasi pati dan kematangan produk. Pemanasan yang terlalu lama akan mengakibatkan cassava chunk pecah dan terjadi gelatinisasi berlebih sehingga perlu dioptimasi kondisi proses termal dan penentuan nilai $F_{0}$ untuk menghasilkan mutu cassava chunk RTE yang aman.

Badan pengawas obat dan makanan Republik Indonesia (BPOM RI) mengeluarkan peraturan kepala BPOM RI no 24 tahun 2016 tentang persyaratan steril komersial. $F_{0}$ adalah ukuran kecukupan panas untuk proses sterilisasi komersial yang dinyatakan sebagai ekivalen waktu pemanasan (dalam satuan menit) pada suhu konstan $121,1^{\circ} \mathrm{C}\left(250^{\circ} \mathrm{F}\right)$. Sterilisasi komersial harus memberikan nilai $F_{0}$ sekurang-kurangnya 3,0 menit, yang dihitung terhadap spora Clostridium botulinum. Penetapan kecukupan panas harus dilakukan untuk setiap jenis produk, jenis medium, ukuran produk, dan faktor kritis lain yang berpotensi memengaruhi nilai $F_{0}$. Penelitian ini bertujuan untuk mendapatkan nilai $F_{0}$ berdasarkan perlakuan blansir dan tanpa blansir serta karakteristik kimia cassava chunk.

\section{METODE PENELITIAN}

\section{Bahan dan Alat}

Bahan utama yang digunakan dalam penelitian ini adalah singkong ketan atau varietas Manggu Bogor umur panen 9 bulan yang diperoleh dari petani di Desa Carang Pulang, Bogor, larutan garam 1\%, kemasan hermetis standing pouch 7,12 x 5,08 x 1,10 inchi (spesifikasi nylon 15, LLDPE 50-100) dari PT Norita Flexindo Bogor.

Alat yang digunakan dalam penelitian ini adalah $\mathrm{pH}$ meter (Thermo scientific orion US), aw meter (Rotronic Instruments UK), panci presto merk Nagami $25 \mathrm{~L}$ dengan tambahan desain keranjang yang didesain secara pribadi dengan kapasitas 14 kantong, termokopel, data rekorder (Hioki LRB400-20, Japan), oven, neraca analitik, soxhlet, dan Spektrofotometer UV-VIS (Shimadzu A109349, Japan).

\section{Waktu dan Tempat}

Penelitian dilaksanakan pada bulan Juni 2019Maret 2020 di Laboratorium Pengolahan Pangan, Laboratorium Sensori, Laboratorium Kimia, dan Labo- 
ratorium Biokimia, Departemen Ilmu dan Teknologi Pangan, IPB.

\section{Karakterisasi Bahan Baku}

Persiapan bahan baku meliputi sortasi, pengupasan, pemotongan, dan pembersihan. Selanjutnya dilakukan karakterisasi bahan baku, yaitu pengukuran $\mathrm{pH}$ (AOAC 2012) dan aw yang diukur dengan aw meter (Higrolab Model Rotronik), dan analisis proksimat (AOAC 2012).

\section{Penentuan Ukuran Potongan serta Jumlah Larutan Garam \\ Ukuran yang dioptimasi adalah panjang dan jari-jari} $8 \times 2,5 \mathrm{~cm}$ dan $3 \times 2,5 \mathrm{~cm}$. Umbi yang berbentuk silinder yang telah dikupas dibagi menjadi empat bagian dan dipotong sesuai dengan ukuran yang ditentukan agar mudah dikonsumsi. Potongan singkong diblansir/dikukus selama 5 menit. Potongan singkong dikemas dalam kemasan yang tahan panas, diisi larutan garam konsentrasi $1 \%$ yang telah dimasak hingga mendidih. Jumlah larutan garam yang digunakan adalah $20 \%, 30 \%, 40 \%$, dan $50 \%$ yang dihitung dari $200 \mathrm{~g}$ potongan singkong setiap kemasan. Kondisi larutan garam ditambahkan dalam keadaan panas dengan suhu sekitar $40^{\circ} \mathrm{C}$. Kemasan yang sudah terisi sampel dikemas dengan vacum sealer. Selanjutnya disterilisasi selama 45 menit pada suhu $111^{\circ} \mathrm{C}$ dalam panci presto dengan menggunakan api kompor yang besar. Tahapan ini bertujuan untuk melihat tingkat kesukaan panelis terhadap cassava chunk dengan uji rating hedonik. Panelis yang ikut dalam pegujian sebanyak 45 orang. Analisis yang dilakukan mencakup warna, rasa, aroma, dan tekstur.

Nilai skala yang digunakan adalah uji rating hedonik 1-6 yang mengindikasikan penilaian dari sangat tidak suka (1) hingga sangat suka (6). Setiap panelis memperoleh 8 sampel yang telah disterilisasi. Data yang diperoleh dianalisis dengan Analysys of Variance (ANOVA). Jika pada hasil pengujian terdapat signifikansi perbedaan pada taraf $5 \%$ maka dilanjutkan dengan uji Duncan.

\section{Penentuan Nilai $F_{0}$ \\ - Persiapan sampel}

Produk yang terpilih dari hasil optimasi diukur karakteristik proses termalnya. Pengolahan singkong potong dengan cara sterilisasi menggunakan plastik kemasan hermetis standing pouch dalam panci presto. Singkong dikupas dan dipotong dengan ukuran panjang $3 \mathrm{~cm}$ dan jari-jari $2,5 \mathrm{~cm}$ diblansir/dikukus selama 5 menit dengan kondisi air di kukusan yang sedang mendidih dan sebagian sampel tidak mendapat perlakuan blansir di awal untuk melihat perbedaan $F_{0}$ yang dihasilkan setelah sterilisasi. Singkong dalam keadaan masih panas ditimbang $200 \mathrm{~g}$ ditambah larutan garam dengan konsentrasi $1 \%$ sebanyak $40 \mathrm{~mL}$ (larutan kondisi panas $40^{\circ} \mathrm{C}$ ) sehingga total netto 240 g dalam kemasan. Kemasan yang telah diisi dikemas vakum untuk membuang udara dalam kemasan dan disterilisasi pada suhu $111^{\circ} \mathrm{C}$ selama 45 menit terhitung dari suhu cut off time panci presto. Setelah sterilisasi, kompor dimatikan, didiamkan 15 menit lalu disiram dengan air mengalir melalui salah satu tempat aliran udara pada panci presto.

\section{- Pengukuran penetrasi panas (IFTS 1992)}

Pengukuran penetrasi panas dilakukan dengan cara memasang termokopel pada bagian tengah potongan umbi dalam kemasan (Gambar 1). Probe dipasangkan pada sembilan kemasan produk cassava chunk. Kemasan pouch sebanyak 14 buah yang berisi potongan umbi cassava disusun dalam satu tumpukan keranjang yang diisi air dengan tinggi $6,5 \mathrm{~cm}$ atau sampai batasan saringan/keranjang. Setiap menit rekorder mencatat perubahan suhu produk terhadap waktu dalam kemasan. Pengukuran ini dilakukan untuk menentukan bagian terdingin dalam presto dan menentukan Come up time (CUT) dengan suhu target $111^{\circ} \mathrm{C}$ selama 45 menit. Suhu ditepatkan pada skala logaritmis (sumbu y), sedangkan waktu pada skala linear (sumbu x).

\section{- Perhitungan waktu sterilisasi optimum metode umum (Toledo 2007)}

Waktu sterilitas didapatkan dari nilai sterilitas proses yang dihitung dari luasan daerah di bawah kurva semilogaritma. Untuk keperluan ini, bentuk luasan di bawah kurva kemudian dihitung. Untuk menghitung luasnya daerah tersebut maka daerah di bawah kurva dibagi menjadi sejumlah pararelogram pada interval waktu tertentu. Masing-masing dihitung nilai luasnya untuk mendapatkan nilai lethal rate (LR) dari kenaikan suhu dari $t=0$ sampai pemanasan selama t menit dengan suhu acuan untuk sterilisasi sebesar $121,11^{\circ} \mathrm{C}$. Untuk nilai $\mathrm{Z}$ bakteri Clostridium botulinum adalah $10^{\circ} \mathrm{C}$ untuk mengurangi populasi bakteri sebesar 1 siklus logaritma atau satu desimal. Selanjutnya sterilisasi parsial ( $F_{0}$ parsial) pada interval waktu tersebut dijumlahkan untuk mendapatkan sterilitas total yang telah dilakukan. Rumus perhitungan nilai Lethal rate di mana nilai $Z$ adalah 10 dan $F_{0}$ parsial dapat dilihat sebagai berikut. Suhu acuan untuk sterilisasi adalah $121.11^{\circ} \mathrm{C}$ di mana t merupakan kenaikan suhu.

$$
\begin{gathered}
L R=L V=10^{\left[\frac{T-121.11}{Z}\right]} \\
\mathrm{F}_{\mathrm{O}} \text { parsial }=\left(\frac{\mathrm{L} V_{t n}+\mathrm{LV}_{t n+A t}}{2}\right) \Delta t
\end{gathered}
$$

\section{- Analisis karakteristik kimia}

Analisis proksimat produk cassava chunk terpilih meliputi analisis kadar air metode oven, analisis kadar abu dengan tanur, analisis protein dengan metode Kjeldhal, analisis kadar lemak dengan metode Soxhlet, dan serat pangan dengan metode AOAC (2012) serta kadar pati dengan metode Sani et al. (2014). 

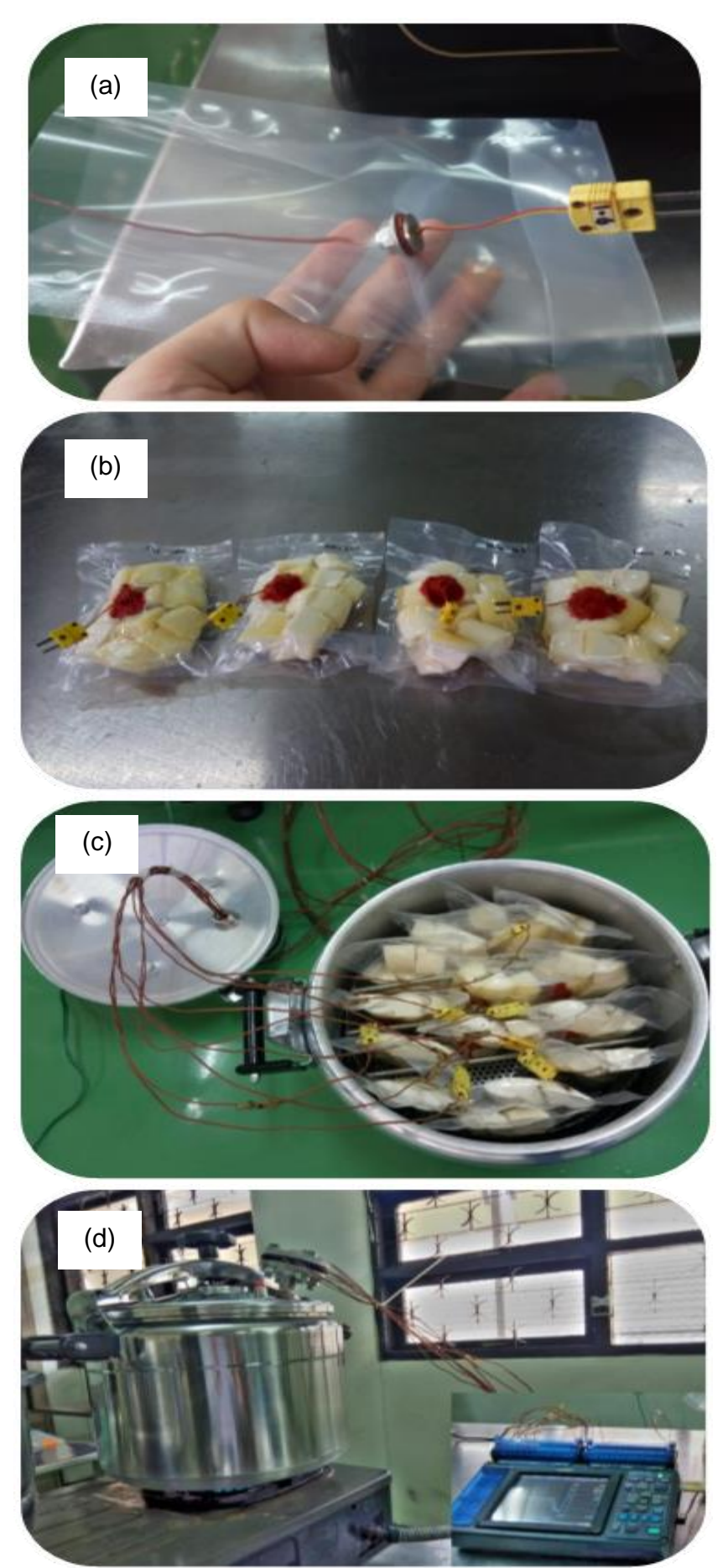

Gambar 1 Tahapan pengukuran penetrasi panas produk cassava chunk. a) Pemasangan termokopel; b) Pemasangan kabel pada bagian tengah umbi; c) Pengaturan letak termokopel; dan d) Perekaman data.

\section{HASIL DAN PEMBAHASAN}

\section{Karakterisasi Singkong dan Penampakan Produk}

Produk singkong dianalisis $\mathrm{pH}, \mathrm{a}_{\mathrm{w}}$, dan komposisi proksimatnya. Berdasarkan hasil pengukuran, singkong memiliki pH sebesar 6,70 $\pm 0,01$ dan memiliki $a_{w}$ $0,9 \pm 0,03$ pada suhu $24,6^{\circ} \mathrm{C}$. Pertimbangan utama dalam merancang proses termal, pertama sekali perlu dipahami sifat intrinsik bahan pangan yang paling dominan memengaruhi proses termal. Bahan pangan memerlukan suhu dan waktu yang tepat untuk membatasi pertumbuhan patogen atau pembentukan racun yang bisa mengancam kesehatan publik. Karakteristik dominan yang memengaruhi potensi bahaya bahan pangan adalah aktivitas air $\left(a_{w}\right)$ dan tingkat keasaman $(\mathrm{pH})$. Berdasarkan $\mathrm{pH}$ dan $\mathrm{a}_{\mathrm{w}}$ yang telah diukur, singkong digolongkan pada bahan pangan dengan potensi bahaya tinggi karena memiliki nilai $a_{w} \geq 0,85$ dan $\mathrm{pH} \geq 4,6$. Berdasarkan peraturan FDA, makanan dengan aw lebih besar dari 0,85 dan $\mathrm{pH}$ lebih besar dari 4.6 dikelompokkan sebagai makanan berasam rendah, dan apabila disimpan pada suhu ruang, produk pangan tersebut harus diproses dengan sterilisasi.

Cassava chunk merupakan produk baru yang memiliki bentuk yang masih seperti potongan singkong segar. Pangan utuh ini dihasilkan melalui sterilisasi produk dan teknologi pengalengan menggunakan kemasan hermetis. Cassava chunk adalah olahan langsung berupa potongan atau irisan singkong yang diolah melalui pengupasan, pengukusan/blansir, penempatan dalam wadah hermetis, pengisian larutan garam dan sterilisasi. Produk ini diharapkan bisa diolah dalam skala industri agar tersedia di pasaran dan masyarakat tertarik untuk mengonsumsinya. Cassava chunk memiliki rasa yang enak karena adanya penambahan larutan garam konsentrasi $1 \%$.

\section{Hasil Optimasi Ukuran Potongan serta Jumlah Larutan Garam}

Tahap ini dilakukan untuk mencari tipe ukuran potongan serta perbandingan jumlah larutan garam terbaik. Salah satu penentuan produk terpilih berdasarkan pada hasil uji rating hedonik (kesukaan) dengan menggunakan 45 orang panelis tidak terlatih. Skala 6 poin digunakan dengan dasar untuk menghindari panelis memberikan penilaian netral. Nilai netral pada pengembangan produk tidak dikehendaki karena tidak dapat diketahui apakah panelis menyukai atau tidak menyukai (Moskowitz et al. 2005). Penentuan produk terpilih dilakukan berdasarkan nilai tertinggi dari total penjumlahan nilai skala semua atribut pada setiap sampel perlakuan.

Uji Duncan menunjukkan bahwa semakin tinggi penambahan larutan garam semakin menurun nilai kesukaan panelis terhadap cassava chunk. Pada atribut warna, perlakuan penambahan larutan garam $30 \%, 40 \%$, dan $50 \%$, tidak berbeda nyata $(P>0,05)$, sedangkan penambahan larutan garam $20 \%$ berbeda dari semua perlakuan dan mendapat nilai kesukaan paling tinggi. Hasil uji Duncan menunjukkan untuk atribut aroma tidak berbeda nyata pada perlakuan penambahan larutan garam $20 \%, 30 \%, 40 \%$, dan $50 \%$. Cassava chunk yang dihasilkan memiliki aroma yang sama sekitar 4, yaitu kategori agak suka. Untuk atribut rasa, hasil uji Duncan menunjukkan bahwa perlakuan penambahan larutan garam $20 \%$ diperoleh nilai skala 
kesukaan paling tinggi 4,53 (agak suka hingga suka) dan respons panelis terhadap penambahan larutan garam $30 \%, 40 \%$, dan $50 \%$ (agak tidak suka hingga agak suka) adalah berbeda nyata. Atribut tekstur mendapat poin kesukaan tertinggi pada penambahan larutan garam $20 \%$, yaitu 4,8 yang merupakan tekstur yang disukai panelis. Secara keseluruhan, cassava chunk yang paling disukai adalah cassava chunk yanbg diolah dengan penambahan larutan garam 20\% dan dipilih menjadi formulasi produk terpilih untuk proses pengalengan dan sterilisasi cassava chunk pada tahap selanjutnya. Secara lebih rinci hasil pengukuran ini dapat dilihat pada Tabel 1.

Nilai kesukaan panelis berdasarkan tipe ukuran dapat dilihat pada Tabel 2. Perlakuan tipe ukuran $3 x$ $2,5 \mathrm{~cm}$ dan $8 \times 2,5 \mathrm{~cm}$ pada cassava chunk tidak memengaruhi tingkat kesukaan panelis. Hasil penilaian kesukaan panelis pada atribut warna, aroma, rasa, tekstur, dan keseluruhan pada kedua tipe ukuran berada pada skor 4 , yaitu agak suka hingga suka. Tipe ukuran yang dipilih adalah $3 \times 2,5 \mathrm{~cm}$ karena memiliki nilai kesukaan yang paling tinggi dibandingkan dengan ukuran $8 \times 2,5 \mathrm{~cm}$. Penjumlahan skor kesukaan tipe ukuran $3 \times 2,5 \mathrm{~cm}$ adalah 21,45 , sedangkan tipe ukuran $8 \times 2,5 \mathrm{~cm}$ adalah 21,25 .

\section{Kecukupan Proses Sterilisasi (Nilai $\mathrm{F}_{0}$ )}

Pengukuran distribusi panas tidak dilakukan pada panci tanpa produk dengan asumsi bahwa suhu dalam panci presto tersebar merata, tetapi langsung saja penetrasi panas produk. Pada kurva hasil uji penetrasi panas (Gambar 2) nilai suhu minimum yang dicapai produk tiap satuan waktu dikelompokkan. Pengujian menggunakan 9 termokopel pada titik yang berbeda di dalam presto yang diduga lambat menerima panas. Presto dijalankan dengan suhu target $111^{\circ} \mathrm{C}$ selama 45 menit terhitung pada saat cut of time (CUT), yaitu pada menit ke-33. Acuan suhu digunakan karena suhu panci presto merk Nagami tertinggi yang terukur adalah $111^{\circ} \mathrm{C}$. Suhu minimum akan dijadikan acuan perhitungan pengukuran $\mathrm{F}_{0}$ target yang ingin dicapai, yaitu 3 yang merupakan nilai $F_{0}$ minimal untuk target penurunan Clostridium botulinum. Bakteri ini menjadi indikator pada makanan kaleng karena kondisi makanan kaleng yang vakum sangat cocok bagi pertumbuhan bakteri $C$. botulinum yang bersifat anaerobik yang tumbuh pada pangan berasam rendah

Tabel 1 Hasil rata-rat uji organoleptik

\begin{tabular}{cccrrc}
\hline Larutan garam (\%) & Warna & \multicolumn{1}{c}{ Aroma } & \multicolumn{1}{c}{ Rasa } & \multicolumn{1}{c}{ Tekstur } & Keseluruhan \\
\hline 20 & $4,80^{\mathrm{a}} \pm 0,84$ & $4,37^{\mathrm{a}} \pm 1,08$ & $4,53^{\mathrm{a}} \pm 1,05$ & $4,80^{\mathrm{a}} \pm 0,85$ & $4,58^{\mathrm{a}} \pm 0,84$ \\
30 & $4,52^{\mathrm{b}} \pm 0,79$ & $4,23^{\mathrm{a}} \pm 0,91$ & $3,97^{\mathrm{b}} \pm 1,01$ & $3,92^{\mathrm{bc}} \pm 1,09$ & $4,03^{\mathrm{b}} \pm 0,88$ \\
40 & $4,36^{\mathrm{b}} \pm 0,97$ & $4,11^{\mathrm{a}} \pm 0,96$ & $3,99^{\mathrm{b}} \pm 1,12$ & $3,79^{\mathrm{c}} \pm 1,33$ & $4,06^{\mathrm{b}} \pm 0,98$ \\
50 & $4,43^{\mathrm{b}} \pm 1,00$ & $4,33^{\mathrm{a}} \pm 1,09$ & $4,11^{\mathrm{b}} \pm 1,22$ & $4,18^{\mathrm{b}} \pm 1,26$ & $4,28^{\mathrm{b}} \pm 1,02$ \\
\hline
\end{tabular}

Keterangan: Huruf kecil yang berbeda pada kolom yang sama menunjukkan perbedaan yang signifikan $(p<0,05)$.

Tabel 2 Hasil rata-rat uji organoleptik berdasarkan tipe ukuran

\begin{tabular}{ccccccc}
\hline Ukuran $(\mathrm{cm})$ & Warna & Aroma & Rasa & Tekstur & Keseluruhan & Total skor \\
\hline $3 \times 2,5$ & $4,55 \pm 0,93$ & $4,23 \pm 1,04$ & $4,13 \pm 1,09$ & $4,27 \pm 1,21$ & $4,27 \pm 0,94$ & 21,45 \\
$8 \times 2,5$ & $4,51 \pm 0,92$ & $4,29 \pm 0,99$ & $4,17 \pm 1,15$ & $4,07 \pm 1,21$ & $4,21 \pm 0,97$ & 21,25 \\
Nilai p & 0,64 & 0,53 & 0,70 & 0,10 & 0,54 & \\
\hline
\end{tabular}

Keterangan: Nilai signifikansi menunjukkan tidak ada perbedaan yang signifikan $(p>0,05)$.

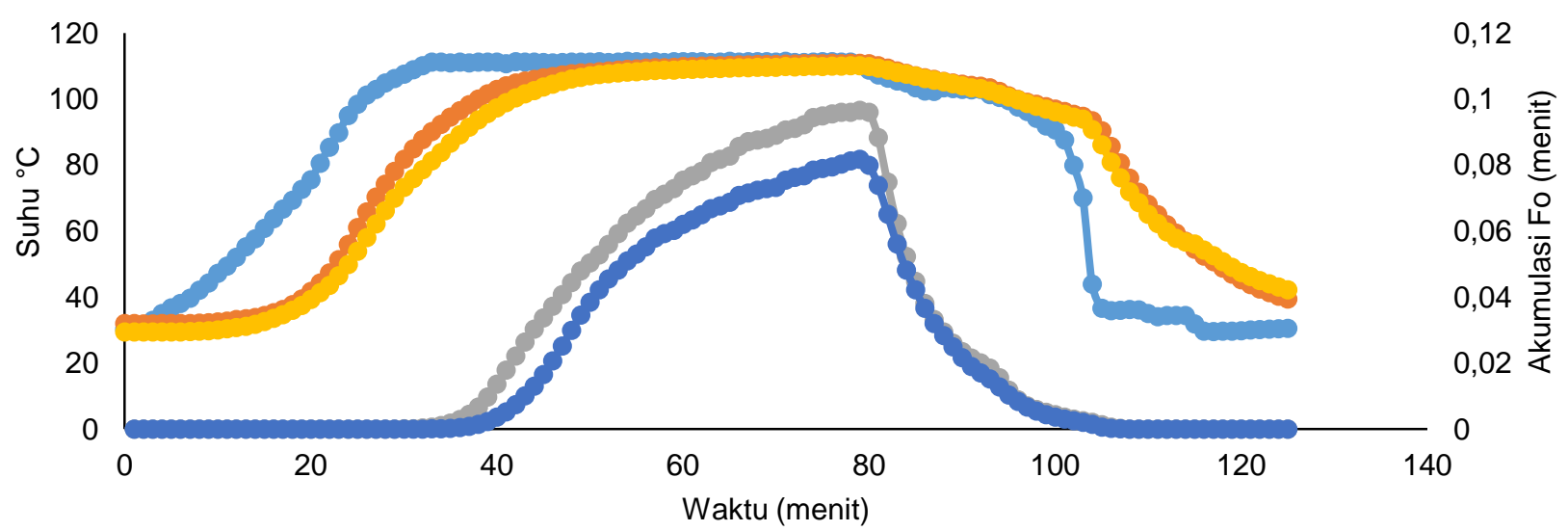

$\longrightarrow$ TC Ruang oC $\longrightarrow$ T cp blansir oC $\longrightarrow$ cp tanpa blansir $0 \mathrm{C} \longrightarrow$ Fo blansir $\longrightarrow$ Fo tanpa blansir 
$(\mathrm{pH}>4,6)$ dan $\mathrm{a}_{w}>0,85$ pada suhu $30-37^{\circ} \mathrm{C}$ (Hariyadi 2018). Syarat steril komersial dalam PERKBPOM RI No 24 tahun 2016 di mana pangan asam rendah harus dikemas dalam kemasan hermetis dan disimpan pada suhu ruang yang harus disterilisasi secara komersial untuk memberikan nilai $F_{0}$ sekurang-kurangnya 3.0 menit dihitung berdasarkan spora Clostridium botulinum.

Cassava chunk yang diblansir selama 5 menit sebelum dikemas mempunyai nilai $F_{0}$ sebesar 3,43 menit yang menyatakan proses telah memenuhi kecukupan panas. Sementara itu, cassava chunk yang tidak diblansir memiliki nilai $\mathrm{F}_{0}$ hanya sebesar 2,77 menit, artinya belum memenuhi kecukupan panas. Perlakuan panas seperti blansir pada cassava memengaruhi teksturnya menjadi lebih lunak dan warna umbi tidak cepat mencokelat pada saat pengolahan. Perlakuan blansir ini menyebabkan perbedaan suhu awal produk, yaitu suhu produk blansing yang terukur, yaitu $32^{\circ} \mathrm{C}$ dan tanpa blansing suhu produk hanya mencapai $29,45^{\circ} \mathrm{C}$. Perambatan panas secara konveksi menyebabkan perubahan struktur jaringan bahan yang mengakibatkan peningkatan porositas dinding sel dan terjadi peningkatan perpindahan massa (Ando et al. 2016). Pelunakan tekstur inilah yang menyebabkan cassava yang diblansir lebih cepat mencapai suhu minimum dengan $\mathrm{F}_{0}$ yang lebih rendah.

\section{Karakterisasi Kimia Singkong dan Cassava Chunk Sterilisasi}

Berdasarkan Tabel 3 dapat dilihat komposisi proksimat singkong segar dan produk cassava chunk hasil sterilisasi. Secara keseluruhan, kadar abu, protein, dan serat tidak larut pada singkong segar tidak berbeda secara statistik pada $p=0,05$ dibandingkan dengan cassava chunk hasil sterilisasi. Kadar air dan kadar pati singkong meningkat setelah sterilisasi. Kadar lemak dan kadar serat pangan larut singkong menurun setelah disterilisasi. Hasil analisis komposisi kimia yang masih sama antara cassava chunk dan singkong segar menunjukkan bahwa produk olahan utuh atau whole food yang dihasilkan dapat menjadi pangan sehat (Zakaria 2015). Kadar air cassava chunk hasil sterilisasi mengalami peningkatan yang cukup signifikan. Hal ini disebabkan karena adanya proses penyerapan air oleh potongan singkong selama dilakukan proses sterilisasi sehingga cassava chunk mengalami peningkatan kadar air.
Kadar abu cassava chunk hasil sterilisasi (3,85\%) mengalami sedikit penurunan dibandingkan dengan kadar abu singkong segar $(4,06 \%)$. Penurunan ini dapat disebabkan oleh kemungkinan terjadinya difusi beberapa mineral larut air tertentu ke dalam air perendaman, pencucian, dan air pemasakan. Penelitian kadar abu pada field peas mengalami penurunan setelah melalui proses perendaman dan pemasakan (Wang et al. 2008).

Salah satu penelitian yang mengevaluasi bahan baku biji Sphenostylis stenocarpa dan efek pengolahannya pada komposisi proksimat dan komposisi mineral menunjukkan bahwa kadar abu tidak berbeda secara signifikan $(P>0,05)$ antara bahan yang diproses dan bahan mentah yang tidak direbus (Ndidi et al. 2014).

Kadar lemak menunjukkan pebedaan yang signifikan setelah mendapat perlakuan sterilisasi. Cassava chunk mengalami penurunan kadar lemak dari $1,54 \%$ pada singkong segar menjadi $0,65 \%$ pada cassava chunk sterilisasi. Sifat lemak yang tidak tahan panas membuat lemak mencair dan menguap, terutama pada saat proses blansir dan kerusakan lemak lainnya pada saat proses sterilisasi. Pengolahan dengan metode pemanasan bisa memecah komponen lemak menjadi produk yang mudah menguap, seperti aldehida, keton, alkohol, dan hidrokarbon (Weber et al. 2008; Purwaningsih et al. 2016).

Kadar pati mengalami peningkatan setelah sterilisasi karena pemanasan menyebabkan kerusakan struktur karbohidrat maupun pati (Woo et al. 2015). Pemanasan karbohidrat akan menyebabkan ikatan hidrogen banyak yang terekspos sehingga beberapa ikatan double helix fraksi amilopektin meregang dan terlepas. Kenaikan kadar pati disebabkan oleh pembengkakan molekul granula pati atau gelatinisasi akibat pemanasan dan keadaan ini berkorelasi dengan penambahan air dalam kemasan sebagai media panas (Haryanti et al. 2014).

Perlakuan sterilisasi tidak berpengaruh nyata pada kandungan serat pangan tidak larut, tetapi berpengaruh nyata pada serat pangan larut. Serat pangan larut mengalami penurunan dari $6.78 \%$ pada singkong segar menjadi $3.34 \%$ pada cassava chunk $(p<0,05)$. Perlakuan panas akan menyebabkan terjadinya pemutusan ikatan polisakarida dan juga dapat merusak ikatan glikosida sehingga menghasilkan monosakarida dan polisakarida. Hal ini terjadi karena adanya penambahan air pada kemasan sebelum

Tabel 3 Komposisi kimia singkong dan produk cassava chunk (b/k)

\begin{tabular}{lcc}
\hline \multicolumn{1}{c}{ Paramater (\%) } & Singkong & Cassava chunk \\
\hline Kadar air & $60,89 \pm 0,000^{*}$ & $68,44 \pm 0,510^{\star *}$ \\
Kadar abu & $4,06 \pm 0,002^{*}$ & $3,85 \pm 0,008^{*}$ \\
Kadar lemak & $1,54 \pm 0,017^{*}$ & $0,65 \pm 0,003^{* *}$ \\
Kadar protein & $1,45 \pm 0,030^{*}$ & $1,65 \pm 0,003^{*}$ \\
Kadar pati & $74,43 \pm 1,780^{*}$ & $80,41 \pm 2,330^{* *}$ \\
$\quad$ Serat pangan larut & $6,78 \pm 1,260^{*}$ & $3,34 \pm 0,690^{\star *}$ \\
\multicolumn{1}{c}{ Serat pangan tidak larut } & $12,48 \pm 1,420^{*}$ & $11,21 \pm 1,100^{*}$ \\
\hline
\end{tabular}

Keterangan: Tanda * yang berbeda pada baris yang sama menunjukkan perbedaan yang signifikan $(p<0,05)$. 
disterilisasi, ketika dipanaskan pada suhu dan tekanan tinggi, serat pangan larut akan terlarut dalam air. Hasil penelitian menunjukkan komposisi serat tidak larut jauh lebih tinggi dibandingkan serat larut. Penelitian tentang komposisi serat ini menunjukkan hal yang berbeda pada tepung talas, yaitu perlakuan pemanasan bertekanan-pendinginan berpengaruh nyata $(p<0,05)$ mampu meningkatkan kadar serat pangan total, namun hasil menunjukkan kadar serat pangan tidak larut jauh lebih tinggi dibandingkan dengan serat pangan larut (Setiarto et al. 2015).

\section{KESIMPULAN}

Teknologi sterilisasi dapat diterapkan untuk menghasilkan produk singkong siap santap yang diberi nama cassava chunk yang dapat mempertahankan nilai gizi dan aman dikonsumsi karena nilai $F_{0}$ lebih dari tiga. Hasil optimasi pembuatan produk cassava chunk didapat tipe $3 \times 2,5 \mathrm{~cm}$ dan larutan garam $20 \%$ dengan perlakuan blansir 5 menit memiliki nilai $F_{0} 3,43$ menit pada suhu $111^{\circ} \mathrm{C}$ selama 45 menit. Kadar lemak dan serat pangan larut mengalami penurunan, sedangkan kadar air dan kadar pati mengalami peningkatan setelah disterilisasi. Kadar abu, protein, dan serat pangan tidak larut pada cassava chunk tidak berbeda nyata dibandingkan dengan pada singkong segar. Produk ini diharapkan dapat menggantikan sebagian konsumsi nasi.

\section{UCAPAN TERIMA KASIH}

Ucapan terima kasih ditujukan kepada donatur dana penelitian dan berbagai pihak yang sangat krusial dalam jalannya penelitian. Penelitian ini didukung oleh dana proyek penelitian "pengolahan cassava untuk menghasilkan produk pangan sehat pengganti nasi" merupakan program penelitian terapan unggulan perguruan tinggi (PTUPT) 2019 yang diketuai oleh Prof. Dr.Ir. Fransiska Rungkat Zakaria, M.Sc

\section{DAFTAR PUSTAKA}

Ando Y, Maeda Y, Mizutani K, Wakatsuki N, Hagiwara S, Nabetani H. 2016. Impact of blanching and freeze-thaw pretreatment on drying rate of carrot roots in relation to changes in cell membrane function and cell wall structure: $L W T$-Food Science Technology. 71: 40-46. https://doi.org/10.1016/ j.Iwt.2016.03.019

[AOAC] Association of Official Analytical Chemistry. 2012. Official Methods of Analysis. New York (US): Marcel Decker.

[BPS] Badan Pusat Statistik. 2019. Produksi ubi kayu menurut provinsi (ton), 1993-2015.Badan Pusat Statistik.[diunduh 2019 Apr 27]. Tersedia pada:
https://www.bps.go.id/linkTableDinamis/view/id/88 0

Eleazu CO. 2016. The concept of low glycemic index and glycemic load foods as panacea for type 2 diabetes mellitus; prospects, challenges and solutions: African. Health Science. 16(2): 468-479. https://doi.org/10.4314/ahs.v16i2.15

Eleazu CO, Eleazu KC, Iroaganachi MA. 2015. Effect of cocoyam (Colocasia esculenta), unripe plantain (Musa paradisiaca) or their combination on glycated hemoglobin, lipogenic enzymes, and lipid metabolism of streptozotocin-induced diabetic rats: Pharmaceutical Biology. 54(1): 1-7. https://doi.org/10.3109/13880209.2015.1016181

Feliana $\mathrm{F}$, Laenggeng $\mathrm{AH}$, Program $\mathrm{M}$, Pendidikan $\mathrm{S}$, Untad B, Program D, Pendidikan S, Untad B. 2014. Berdasarkan Umur Panen Di Desa Siney Kecamatan: e-jipbiol.2(3).

Hariyadi P. 2018. Teknologi Proses Termal untuk Industri Pangan. Bogor: PT Media Pangan Indonesia.

Haryanti P, Setyawati R, Wicaksono R. 2014. Pengaruh Suhu Dan Lama Pemanasan Suspensi Pati Serta Konsentrasi Butanol Terhadap Karakteristik Fisikokimia Pati Tinggi Amilosa Dari Tapioka. Jurnal Agritech. 34(03): 308-315 https://doi.org/10.22146/agritech.9459

IFTPS. 1992. Temperature Distribution Protocol for Processing in Steam Still Retorts, Excluding Crateless Retorts: Institute for Thermal Processing Specialist. Fairfax,VA

Infante RB, García OO, Rivera C. 2013. Characterization of dietary fiber and pectin of cassava bread obtained from different regions of Venezuela: Revista Chilena de Nutricion. 40(2): 169-173. https://doi.org/10.4067/S071775182013000200012

Kumar R, Johnsy G, Rajamanickam R, Lakshmana JH, Kathiravan T, Nataraju S, Nadanasabapathi S. 2013. Effect of gamma irradiation and retort processing on microbial, chemical and sensory quality of ready-to-eat (RTE) chicken pulav: International Food Research Journa.20(4): 1579-1584.

Moskowitz HR, Ph D, Porretta S. 2005. Concept Research in Food Product Design in Food Product Design and Development: Blackwell Publishing Asia. https://doi.org/10.1002/9780470290132

Ndidi US, Ndidi CU, Olagunju A, Muhammad A, Billy FG, Okpe O. 2014. Proximate, Antinutrients and Mineral Composition of Raw and Processed (Boiled and Roasted) Sphenostylis stenocarpa Seeds from Southern Kaduna, Northwest Nigeria: ISRN Nutrition. 2014: 1-9. https://doi.org/10.1155/ 2014/280837 
Post RE, Mainous AG, King DE, Simpson KN. 2012. Dietary fiber for the treatment of type 2 diabetes mellitus: A meta-analysis. Journal of the American Board of Family Medicine. 25(1): 16-23. https://doi.org/10.3122/jabfm.2012.01.110148

Purwaningsih $\mathrm{S}$, Suseno $\mathrm{SH}$, Salamah $\mathrm{E}$, Mulyaningtyas JR, Dewi YP. 2016. Effect of boiling and steaming on the profile fatty acids and cholesterol in muscle tissue of molluscs: International Food Research Journal. 22(3): 1087-1094.

Sani W, Iswadi, Samingan. 2014. Kandungan Pati Pada Bonggol Pisang: Prosiding Seminar Nasional Biologi. Banda Aceh, 27 Desember 2014

Setiarto RHB, Suryaatmadja SL, Faridah DN, Saskiawan I. 2015. Peningkatan Pati Resisten Tepung Talas Melalui Fermentasi Dan Pemanasan Bertekanan-Pendinginan Serta Evaluasi Sifat Prebiotiknya [Tesis]. Bogor (ID): Institut Pertanian Bogor.

Toledo RT. 2007. Fundamentals of Food Process Engineering. Ed ke-3 Heldman DR, editor. New York: Springer Science+Business Media, LLC.

Virat A, Kumar R, Johnsy G, Nataruju S, Lakshmana $\mathrm{JH}$, Kathiravan T, Madhukar N, Nadanasabapathi S. 2014. Development of retort process for ready-toeat (RTE) Soy-peas curry as a meat alternative in multilayer flexible retort pouches: International Food Research journal. 21(4): 1553-1558.

Wang N, Hatcher DW, Gawalko EJ. 2008. Effect of variety and processing on nutrients and certain antinutrients in field peas (Pisum sativum): Food Chemistry 111: 132-138. https://doi.org/10.1016/ j.foodchem.2008.03.047

Weber J, Bochi VC, Ribeiro CP, Victório A de M, Emanuelli T. 2008. Effect of different cooking methods on the oxidation, proximate and fatty acid composition of silver catfish (Rhamdia quelen) fillets: Food Chemistry. 106(1): 140-146. https:// doi.org/10.1016/j.foodchem.2007.05.052

[WHO] world Health Organization.2020. Healthy diet. Diperbaharui 29 April 2020 tersedia pada https://www.who.int/news-room/factsheets/detail/healthy-diet.

Woo KS, Kim HY, Hwang IG, Lee SH, Jeong HS. 2015. Characteristics of the thermal degradation of glucose and maltose solutions. Preventive Nutrition and Food Science. 20(2): 102-109. https:// doi.org/10.3746/pnf.2015.20.2.102

Rungkat FZ. 2015. Pangan Nabati, Utuh dan Fungsional sebagai Penyusun Diet Sehat. $\mathrm{Di}$ dalam: Pangan Untuk Kesejahteraan Masyarakat. Kumpulan Naskah Orasi IImiah Guru Besar Institut Pertanian Bogor. Meryandini A. ed. IPB Press: 283337. 